\title{
MORPHOLOGY, GROWTH VARIABILITY AND CHEMICAL COMPOSITION OF INDIAN AND NIGERIAN ACCESSION OF OCIMUM SPECIES GROWN IN INDIA
}

\author{
Nensi Patel ${ }^{1}$, Nikita Patel ${ }^{1}$, Swetal Patel ${ }^{1}$, Rajashekhar Ingalhalli ${ }^{1}$, Taofeeq Garuba ${ }^{1,3}$, \\ Akeem O. Ahmed ${ }^{1,4}$, Samson A. Oyeyinka ${ }^{1,2}$, Ramar Krishnamurthy ${ }^{1 *}$ \\ ${ }^{I}$ C.G. Bhakta Institute of Biotechnology, Uka Tarsadia University Gujarat, India \\ ${ }^{2}$ Department of Home Economics and Food Science, University of Ilorin, Nigeria \\ ${ }^{3}$ Department of Plant Biology, University of Ilorin, Nigeria \\ ${ }^{3}$ Department of Veterinary Microbiology, University of Ilorin, Nigeria \\ *krishnashanti@gmail.com; krishnamurthy@utu.ac.in
}

https://doi.org/10.34302/2019.11.4.6

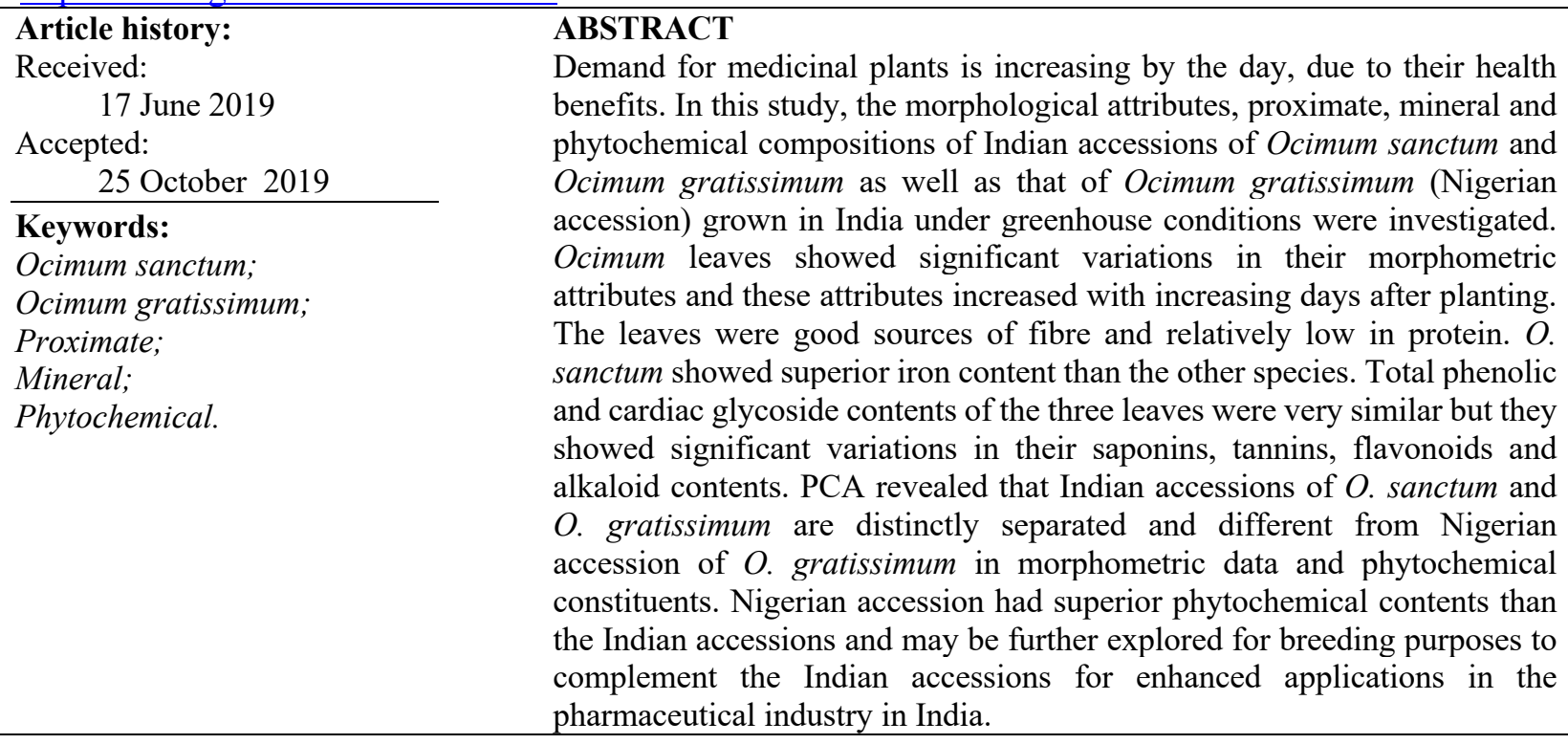

\section{Introduction}

Medicinal plants including the genus Ocimum, are well-known to have healthpromoting benefits and nutraceutical functions. These functions have been associated with the presence of plant components such as proteins, vitamins, fibres, several kinds of secondary metabolites (Bhattacharya et al., 2014), essential oils and phenolic compounds (Joshi et al., 2011). The genus Ocimum belongs to the family Lamiaceae and consist of about 30-35 species indigenous to tropical regions of Asia, Africa, central and south America (Okunlola et al.,
2017; Paton, 1992). These plant species have been reported to possess antidiabetic (Gholap and Kar, 2004), antioxidant (Akinmoladun et al., 2007; Bhattacharya et al., 2014; Joshi et al., 2011; Siti et al., 2018) anti-asthmatic (Singh and Agrawal, 1991), anti-inflammatory (Mequanint et al., 2011; Singh and Agrawal, 1991; Singh et al., 1996), antimicrobial (Dambolena et al., 2010; Joshi et al., 2011; Nakamura et al., 1999), anti-stress (Gupta et al., 2007) and anticancer (Prashar et al., 1998) activities.

The nutritional value of genus the Ocimum may vary with species, growing location and 
processing method. For example, differences in the protein content ( 7 and $25 \%$ ) (Dry weight basis) of these species have been reported in different parts of the world including Nigeria (Okunlola et al., 2017) and India (Barua et al., 2015; Siti et al., 2018). In India, Ocimum sanctum Linn also known as Tulsi or Holy Basil is an Ayurvedic herb of Southeast Asia with a long history of traditional uses (Singh and Chaudhuri, 2018). It is a common specie that is widely grown in many parts of India. Besides the afore-mentioned therapeutic uses of the species, Ocimum sanctum can also be consumed as herbal tea, to treat cough, cold and malaria (Prakash and Gupta, 2005). However, In Nigeria and many African countries, Ocimum americanum, Ocimum basilicum and Ocimum gratissimum are the most important and popular members of these species (Okunlola et al., 2017). Due to the growing demand of medicinal plants in many parts of the world, researchers are now focusing on the possibility of increasing their production either through micropropagation (Okunlola et al., 2017; Saha et al., 2010; Saha et al., 2012) or macro-propagation (Ehiagbonare, 2007). Ocimum species are generally propagated using both seeds and stem cutting, but farmers have problems with cultivating plants from seeds due to their low viability (Okunlola et al., 2017). Many factors such as the method of propagation, specie type, as well as growing conditions may influence the growth pattern and phytochemical constituents of Ocimum plants. Okunlola et al. (2017), recently studied the growth and nutritional qualities of Ocimum basilicum, Осimum gratissimum, and Ocimum americanum, propagated by stem cutting and seed. According to their report, Ocimum species propagated by stem cutting performed better in terms of morphometric attributes than those propagated through the seed. For instance, Ocimum gratissimum propagated through the stem had higher number (8 times) of branches and were taller (4 times) than the same specie propagated by seed (Okunlola et al., 2017). However, seed propagated samples contained more phytochemicals than those propagated by stem cutting, suggesting that seed propagation may be better in growing Ocimum species for pharmaceutical applications. Hence, in this study, the morphological and growth variability as well as the proximate, mineral and phytochemical composition of Ocimum sanctum and Ocimum gratissimum were investigated.

\section{Materials and methods}

\subsection{Plant materials}

Seeds of three Ocimum species were used in this study. Indian accessions of Ocimum gratissimum and Ocimum sanctum were collected from Maliba Pharmacy College, Uka Tarsadia University (UTU), Gujarat, India, while seeds of one Nigerian accession of Ocimum gratissimum was obtained from the botanical garden of University of Ilorin, Nigeria. Body text TNR 12 normal, ident first line 0.66 $\mathrm{cm}$, line spacing Single)

\subsection{Seed propagation and processing}

Ocimum seeds were sown in the greenhouse of UTU and growth was monitored for 3, 60 and 90 days after planting. Fresh plant leaves of the Indian and Nigerian accessions were collected and washed thoroughly using distilled water. Leaves were separated for different analysis including proximate mineral and photochemical screening as described below. Samples for phytochemical screening were air-dried under shaded condition at room temperature. The dried leaves were crushed into powder and stored in sealed bottles until needed.

\subsection{Qualitative and quantitative screening of phytochemicals}

Alkaloids, tannins, cardiac glycosides, flavonoids and saponins were determined as previously described (Sofowora, 1993), while the presence of steroids was determined using the method of Khandelwal (2007). 


\subsection{Proximate composition}

Moisture, fat and ash contents of the samples were determined using AOAC (2000) methods. Dry matter contents of the samples were calculated by deducting percentage moisture content from 100. Protein content was determined by the Kjeldahl method $(6.25 \times \mathrm{N})$ and carbohydrate was calculated by difference. Fibre contents were determined by digestion in sulfuric acid and sodium hydroxide (Kirk and Sawyer, 1991).

\subsection{Mineral composition}

Mineral content of the samples was determined as described by Amonsou et al. (2014) using Inductively Coupled Plasma (ICP) spectroscopy. Samples were acid-digested by the addition of $1 \mathrm{~mL}$ of $55 \%(\mathrm{v} / \mathrm{v}) \mathrm{HNO}$.

\subsection{Statistical analysis}

Duplicate samples were prepared and analyses done in triplicate. Data was analysed using one way analysis of variance (ANOVA) and means were compared using the Fisher Least Significant Difference (LSD) test $(\mathrm{p} \leq 0.05)$ using the Statistical Package for the Social Sciences (SPSS) Version 16.0 for Windows (SPSS Inc., Chicago, IL, USA). Principal component analysis (PCA) was used to determine the similarity and differences in the three Ocimum accessions based on morphometric data and phytochemical constituents.

\section{Results and discussions}

\subsection{Morphometric characteristics}

With the exception of the colour of the leaves and stem, which were generally green and white respectively, the three Ocimum species investigated showed significant $(p<0.05)$ variations in their morphometric characteristics (Table 1). Regardless of the specie, height, number of leaves, leaf length, leaf width leaf area and number of branches increased with increasing days after planting. Nigerian accession of $O$. gratissimum generally had higher height, number of leaves, leaf length, leaf width and leaf area compared with the Indian accessions ( $O$. sanctum and $O$. gratissimum). The height, leaf length, leaf area and number of branches of Indian accession of $O$. sanctum were significantly $(\mathrm{p}<0.05)$ different from those of $O$. gratissimum throughout the period of planting (30-90 days). Previous research similarly found that $O$. gratissimum performed better in morphometric attributes compared to $O$. basilicum and $O$. americanum (Okunlola et al., 2017). The height (approx. 26-38), number of leaves (approx. 21-24), and number of branches (0-4) observed for $O$. gratissimum (both Nigerian and Indian accessions) examined after 60 days (approx. 9 weeks) of planting in this study, were much higher (2-6 times) than values reported for $O$. gratissimum examined after 8 weeks of planting (Okunlola et al., 2017). Variation in the morphometric data could be due to the differences in days after planting as well as the green house growing conditions such as soil type and seed sowing depth. For example, $O$. gratissimum seed sown at $1 \mathrm{~cm}$ depth in humus rich topsoil was reported to have higher germination rate $(80 \%)$ compared to seed sown on river sand $(26.3 \%)$ from of the same sowing depth (Ehiagbonare, 2007).

Table 1. Morphometric characteristics of three Ocimum species grown by seed propagation

\begin{tabular}{|c|c|c|c|c|c|c|c|c|c|}
\hline Species & DAP & Height $(\mathrm{cm})$ & NL & $\mathrm{LL}(\mathrm{cm})$ & $\mathrm{LW}(\mathrm{cm})$ & $\mathrm{LA}\left(\mathrm{cm}^{2}\right)$ & NB & $\mathrm{LC}$ & $\mathrm{SC}$ \\
\hline *Sanctum & 30 & $12.19^{g} \pm 0.05$ & $6.00^{\mathrm{f}} \pm 1.00$ & $3.20^{\mathrm{e}} \pm 0.26$ & $1.67^{\mathrm{e}} \pm 0.06$ & $5.13^{\mathrm{f}} \pm 0.06$ & $0.00^{\mathrm{d}} \pm 0.00$ & Green & White \\
\hline${ }^{*}$ Gratissimum & 30 & $9.27^{\mathrm{h}} \pm 0.16$ & $8.33^{\mathrm{f}} \pm 0.58$ & $2.46^{\mathrm{f}} \pm 0.35$ & $1.61^{\mathrm{e}} \pm 0.01$ & $4.00^{\mathrm{a}} \pm 010$ & $0.00^{\mathrm{d}} \pm 0.00$ & Green & White \\
\hline **Gratissimum & 30 & $12.31^{g} \pm 0.12$ & $11.33^{\mathrm{e}} \pm 0.58$ & $3.03^{\mathrm{ef}} \pm 0.32$ & $2.13^{\mathrm{d}} \pm 0.06$ & $6.27^{\mathrm{fg}_{ \pm}} \pm 0.31$ & $0.00^{\mathrm{d}} \pm 0.00$ & Green & White \\
\hline *Sanctum & 60 & $34.53^{\mathrm{e}} \pm 0.36$ & $23.33^{\text {cd }} \pm 1.52$ & $5.33^{\mathrm{d}} \pm 0.40$ & $3.90^{\mathrm{c}} \pm 0.10$ & $20.67^{\mathrm{e}} \pm 0.05$ & $6.67^{\mathrm{b}} \pm 0.57$ & Green & White \\
\hline *Gratissimum & 60 & $26.02^{\mathrm{f}} \pm 0.12$ & $21.33^{\mathrm{d}} \pm 1.52$ & $7.53^{\mathrm{bc}} \pm 0.40$ & $3.80^{\mathrm{c}} \pm 0.17$ & $28.50^{\mathrm{d}} \pm 0.50$ & $0.00^{\mathrm{d}} \pm 0.00$ & Green & White \\
\hline **Gratissimum & 60 & $37.95^{\mathrm{d}} \pm 0.12$ & $24.33^{\mathrm{c}} \pm 0.58$ & $8.93^{\mathrm{a}} \pm 0.31$ & $5.20^{\mathrm{b}} \pm 0.20$ & $46.67^{b} \pm 1.52$ & $4.33^{\mathrm{c}} \pm 1.52$ & Green & White \\
\hline *Sanctum & 90 & $69.36^{\mathrm{b}} \pm 0.66$ & $58.67^{\mathrm{a}} \pm 3.06$ & $7.20^{\mathrm{a}} \pm 0.20$ & $3.90^{c} \pm 0.10$ & $27.37^{\mathrm{d}} \pm 0.40$ & $10.67^{\mathrm{a}} \pm 1.52$ & Green & White \\
\hline *Gratissimum & 90 & $48.05^{\mathrm{c}} \pm 0.14$ & $42.67^{\mathrm{b}} \pm 0.58$ & $7.90^{\mathrm{b}} \pm 0.30$ & $3.90^{\mathrm{c}} \pm 0.10$ & $30.93^{\mathrm{c}} \pm 0.12$ & $5.33^{\mathrm{bc}} \pm 0.58$ & Green & White \\
\hline **Gratissimum & 90 & $74.87^{\mathrm{a}} \pm 0.37$ & $58.33^{\mathrm{a}} \pm 2.08$ & $9.10^{\mathrm{a}} \pm 0.50$ & $5.47^{\mathrm{a}} \pm 0.31$ & $50.93^{\mathrm{a}} \pm 2.08$ & $10.33^{\mathrm{a}} \pm 0.57$ & Green & White \\
\hline
\end{tabular}

Mean \pm S.D. Means with same superscript within the same column are not significantly $(\mathrm{p}<0.05)$ different.

DAP: Days after planting; LN: Number of leaves; L: Leaf length; LW: Leaf width

LA: Leaf Area; LC: Leaf Colour; SC: Stem colour; NB: Number of branches *Indian accession** Nigerian Accession 


\subsection{Proximate composition}

The proximate composition data of the three Ocimum species are presented in Table 2. Expectedly, the moisture content of the three Ocimum leaves were generally high (average 77\%). O. gratissimum (both Nigerian and Indian accessions) had significantly $(\mathrm{p}<0.05)$ lower moisture values (approx. 74-78\%) than $\mathrm{O}$. sanctum (approx. 80\%). Beside the moisture content, which was the major component of the leaves, ash (average 11\%), followed by fibre $(4.72-8.47 \%)$ were present in fairly good quantities. Protein (0.13-0.21\%), carbohydrate $(1.63-2.53 \%)$ and fat (average $3.31 \%)$ were found in relatively small quantities (Table 2). Nigerian accession and Indian accession of $O$. gratissimum had almost similar composition except in their protein and fibre contents, which could be attributed to inherent differences in the plant species. This seems plausible, since both plants were grown under the same conditions. Although the protein content of the leaves were generally low, Nigerian accession of $O$. gratissimum had slightly higher protein content than other Ocimum species. Similarly low levels (0.20-1.21\%) of protein have been reported for different Ocimum leaves (Idris et al., 2011; Oboh et al., 2009). Some authors, however, reported higher protein values $(2.88-9.10)$ for different Ocimum leaves (Emeka and Chimaobi, 2012; Mlitan et al., 2014; Okunlola et al., 2017; Shuaib et al., 2015). Generally, fresh leafy vegetables have been reported to have low levels of protein, which are mostly in the form of enzymes, rather than acting as a storage pool, as in grains and nuts (Oboh et al., 2009).

\subsection{Mineral composition}

There were significant $(\mathrm{p}<0.05)$ differences in the mineral composition of the three Ocimum leaves (Table 3). Nitrogen (4.28-5.58\%), followed by calcium (2.92-3.58\%), phosphorus (0.38-4.83\%) and potassium (2.05-3.51\%) were the major mineral elements in the leaves. Sodium (0.02-0.92\%) and magnesium (1.17$1.49 \%$ ) were found in relatively small quantities. High levels of potassium in human diet is important for the protection against life- threatening diseases such as hypertension, cardiac dysfunctions and osteoporosis (Demigne et al., 2004; Lewu et al., 2010). Among the microelements, iron (263.01-863.00 ppm) was the major mineral in the leaves. Iron content of $O$. sanctum was substantially higher (about 3 times) than values recorded for the $O$. gratissimum species. The consumption of such foods rich in micronutrients such as iron helps to build a strong immune system and facilitate nutrient absorption, utilisation and digestion (Njoku and Ohia, 2007). Furthermore, iron is known to play a vital role in haemopoiesis, control of infection and cell mediated immunity (Barua et al., 2015; Bhaskaram, 2001). Thus, in addition to the well-known medicinal properties of these leaves, they can also be explored in haematinic applications.

The leaves were fairly good sources of manganese (16.00-40.67 ppm), zinc (19.60$39.33 \mathrm{ppm})$ and copper (25.96-36.27 ppm). The zinc, copper and iron values obtained in this study are in agreement with the literature (Idris et al., 2011; Kashif and Ullah, 2013; Vidhani et al., 2016). Nigerian accession of $O$. gratissimum was lower in nitrogen phosphorus, sodium, magnesium and iron, but higher in manganese and copper compared with the Indian accessions. Nitrogen is important for amino acid and protein production and plays a pivotal role in many critical functions such as photosynthesis in plant. Thus, the lower amount of nitrogen in the $O$. gratissimum (Nigerian accession) may explain why it protein content was higher than the Indian accessions (Table 2).

\subsection{Phytochemical composition}

The three Ocimum leaves showed significant $(p<0.05)$ variations in their phytochemical composition, except in their total phenolic and cardiac glycoside contents, which were very similar (Fig. 1). In general, O. gratissimum (Nigerian and Indian accessions) displayed significantly $(\mathrm{p}<0.05)$ higher alkaloids, tannin, flavonoids and saponin contents compared with $O$. sanctum (Indian accession). However, Nigerian accession of $O$. gratissimum was higher in tannins, flavonoids and saponin 
contents than the other two species. Pachkore and Dhale (2012), working with three Ocimum species reported lower tannin values for Ocimum gratissimum $(0.12 \mathrm{mg} / 100 \mathrm{~g})$ and Ocimum sanctum $(0.42 \mathrm{mg} / 100 \mathrm{~g})$, when compared to values in this study. However, other authors reported substantially higher tannins (3.29-4.60 mg/100 g) and saponins (4.50-6.86 $\mathrm{mg} / 100 \mathrm{~g}$ ) for Ocimum gratissimum cultivated by seed and stem cutting (Okunlola et al., 2017). Variation in the phytochemical constituents may be associated with inherent genetic differences among the species studied in the respective studies as well as the environmental condition of the various growth locations (Okunlola et al., 2017). The phenolic and flavonoid contents recorded in this study were almost 3-6 times higher than values reported for Ocimum leaves in earlier studies (Okunlola et al., 2017; Pachkore and Dhale, 2012).

The relatively higher phenols and flavonoids of the leaves suggest that these species will have high antioxidant activities. Phenols and flavonoids are important groups of secondary metabolites, synthesized by plants and have been previously associated with antioxidative activities (Akinmoladun et al., 2007;
Bhattacharya et al., 2014; Joshi et al., 2011; Siti et al., 2018).

\subsection{Principal component analysis}

Morphometric data and phytochemical constituents of the three accessions were analysed using principal component analysis (PCA). PCA revealed that Indian accessions of $O$. sanctum and $O$. gratissimum are distinctly separated and different from Nigerian accession of $O$. gratissimum in morphometric data and phytochemical constituents, despite growing the three plant under the same greenhouse conditions (Figure not shown). The $O$. sanctum and $O$. gratissimum are also different from each other based on these parameters. The first two principal components (PC) accounted for approximately $92 \%$ of the total variability of the data (Fig. 2). PC1 accounted for approximately $59 \%$ of the total variation and was predominantly a function of total phenolic content, tannin, cardiac glycoside, flavonoids, saponins, plant height, leaf length, leaf width and leaf area. The PC2, which only accounted for $32 \%$ of the total variation was made up of alkaloids, number of leaves and number of branches.

Table 2. Proximate composition of leaves of three Ocimum species at 90 days after planting (\%)

\begin{tabular}{|c|c|c|c|}
\hline Parameters & ${ }^{*}$ Sanctum & ${ }^{*}$ Gratissimum & ${ }^{* *}$ Gratissimum \\
\hline Dry matter & $19.77^{\mathrm{b}} \pm 0.21$ & $27.85^{\mathrm{a}} \pm 0.55$ & $26.07^{\mathrm{a}} \pm 1.33$ \\
\hline Moisture & $80.23^{\mathrm{a}} \pm 0.21$ & $78.15^{\mathrm{b}} \pm 0.55$ & $73.93^{\mathrm{b}} \pm 1.33$ \\
\hline Protein & $0.17^{\mathrm{a}} \pm 0.04$ & $0.13^{\mathrm{b}} \pm 0.02$ & $0.21^{\mathrm{a}} \pm 0.04$ \\
\hline Ash & $10.07^{\mathrm{b}} \pm 0.05$ & $11.27^{\mathrm{a}} \pm 0.31$ & $11.40^{\mathrm{a}} \pm 0.53$ \\
\hline Fibre & $4.72^{\mathrm{b}} \pm 0.10$ & $4.88^{\mathrm{b}} \pm 0.24$ & $8.47^{\mathrm{a}} \pm 0.40$ \\
\hline Fat & $3.18^{\mathrm{b}} \pm 0.07$ & $3.3^{\mathrm{a}} \pm 0.13$ & $3.46^{\mathrm{a}} \pm 0.11$ \\
\hline Carbohydrate & $1.63^{\mathrm{b}} \pm 0.30$ & $2.25^{\mathrm{a}} \pm 0.07$ & $2.53^{\mathrm{a}} \pm 0.39$ \\
\hline
\end{tabular}

Mean \pm S.D. Means with same superscript within the same row are not significantly $(\mathrm{p}<0.05)$ different.

*Indian accession ** Nigerian Accession

Table 3. Mineral composition of leaves of three Ocimum species at 90 days after planting

\begin{tabular}{|c|c|c|c|}
\hline Minerals & ${ }^{*}$ Sanctum & ${ }^{*}$ Gratissimum & ${ }^{*}$ Gratissimum \\
\hline Nitrogen (\%) & $5.58^{\mathrm{a}} \pm 0.39$ & $4.84^{\mathrm{b}} \pm 0.07$ & $4.28^{\mathrm{c}} \pm 0.02$ \\
\hline Phosphorus (\%) & $2.05^{\mathrm{b}} \pm 0.03$ & $4.83^{\mathrm{a}} \pm 0.02$ & $0.38^{\mathrm{c}} \pm 0.02$ \\
\hline Potassium (\%) & $2.04^{\mathrm{c}} \pm 0.04$ & $3.51^{\mathrm{a}} \pm 0.02$ & $2.61^{\mathrm{b}} \pm 0.03$ \\
\hline Sodium (\%) & $0.92^{\mathrm{a}} \pm 0.06$ & $0.08^{\mathrm{b}} \pm 0.02$ & $0.02^{\mathrm{c}} \pm 0.01$ \\
\hline Calcium (\%) & $3.58^{\mathrm{a}} \pm 0.03$ & $2.92^{\mathrm{c}} \pm 0.07$ & $3.13^{\mathrm{b}} \pm 0.06$ \\
\hline
\end{tabular}




\begin{tabular}{|c|c|c|c|}
\hline Magnesium (\%) & $1.49^{\mathrm{a}} \pm 0.03$ & $1.40^{\mathrm{b}} \pm 0.03$ & $1.17^{\mathrm{c}} \pm 0.03$ \\
\hline Iron $(\mathrm{ppm})$ & $863.00^{\mathrm{a}} \pm 1.15$ & $285.00^{\mathrm{b}} \pm 1.53$ & $263.01^{\mathrm{c}} \pm 0.58$ \\
\hline Manganese (ppm) & $16.00^{\mathrm{c}} \pm 2.00$ & $29.00^{\mathrm{b}} \pm 1.00$ & $40.67^{\mathrm{a}} \pm 1.53$ \\
\hline Zinc $(\mathrm{ppm})$ & $39.33^{\mathrm{a}} \pm 0.58$ & $19.60^{\mathrm{c}} \pm 1.22$ & $25.63^{\mathrm{b}} \pm 0.67$ \\
\hline Copper $(\mathrm{ppm})$ & $25.96^{\mathrm{b}} \pm 0.97$ & $26.57^{\mathrm{b}} \pm 0.58$ & $36.27^{\mathrm{d}} \pm 1.18$ \\
\hline
\end{tabular}

Mean \pm S.D. Means with same superscript within the same row are not significantly $(\mathrm{p}<0.05)$ different.

*Indian accession

** Nigerian Accession

$* * *$ Values are expressed in $\%$

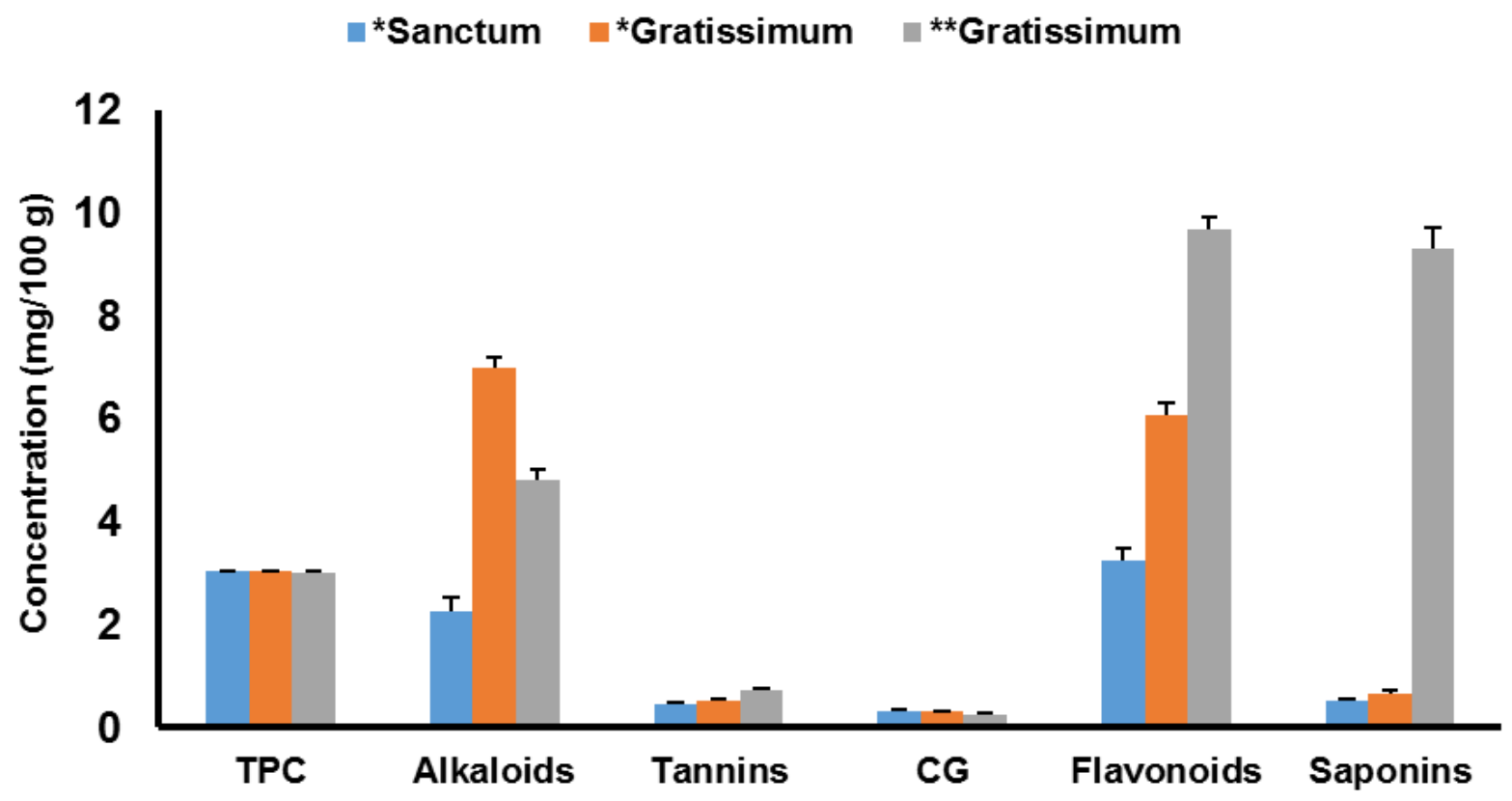

Figure 1. Phytochemical contents of three Ocimum species at 90 days after planting Error bars indicate standard deviation $(\mathrm{N}=3)$

TPC: Total phenolic content

CG: Cardiac glycosides

*Indian accession

** Nigerian Accession 


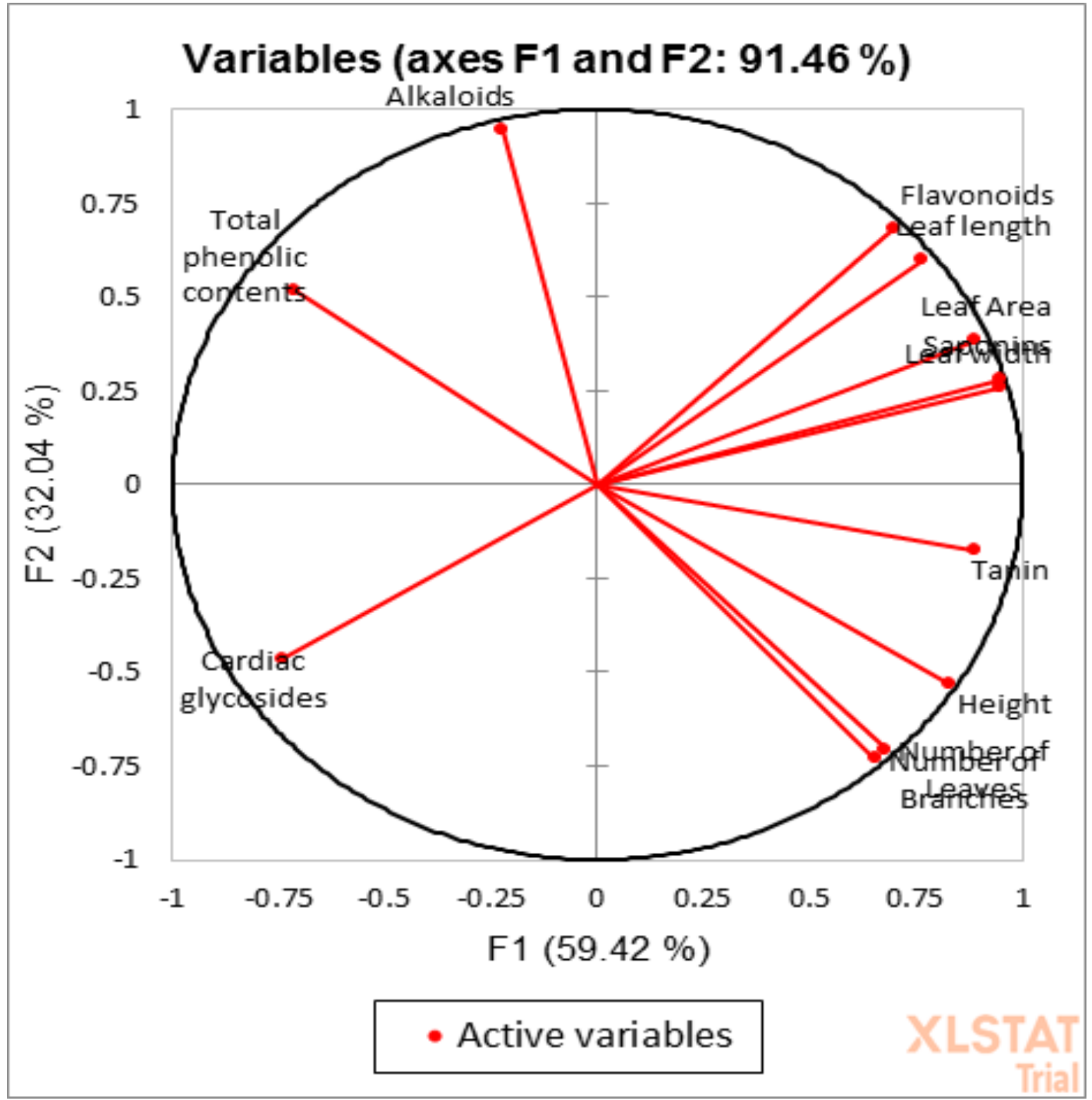

Figure 2. Principal component analysis of morphometric data and phytochemical constituents of Ocimum species

\section{Conclusions}

Nigerian accession of $O$. gratissimum had different morphometric attributes compared with the Indian accessions $(O$. sanctum and $O$. gratissimum), though they were grown under the same greenhouse conditions. All the leaves had relatively low protein content and are fairly good sources of iron, but $O$. sanctum showed superior iron content than the other species. Nigerian accession had superior phytochemical contents than the Indian accessions and may be further explored for breeding purposes through plant tissue culture, to complement the Indian accessions for enhanced applications in the pharmaceutical industry in India. 


\section{References}

Akinmoladun, A. C., Ibukun, E., Afor, E., Obuotor, E., and Farombi, E. (2007). Phytochemical constituent and antioxidant activity of extract from the leaves of Ocimum gratissimum. Scientific Research and Essays, 2, 163-166.

Amonsou, E. O., Siwela, M., and Dlamini, N. (2014). Chemical composition and microstructure of Bauhinia grains. Journal of Food Science and Technology, 51, 22632269.

AOAC. (2000). Offcial methods of analysis. 17th edition. In: Asscoaition of official Analytical Chemists, Rockville.

Barua, C. C., Bora, M., Saikia, B. N., Hazarika, M., and Barua, I. (2015). Quantitative analysis of proximate and mineral composition of a few important medicinal plants of north east region. International Journal of Applied Biology and Pharmaceutical Technology, 6, 188-193.

Bhaskaram, P. (2001). Immunobiology of mild micronutrient deficiencies. British Journal of Nutrition, 85, S75-S80.

Bhattacharya, A., Aggarwal, A., Sharma, N., and Cheema, J. (2014). Evaluation of some anti-oxidative constituents of three species of Ocimum. International Journal of Life Sciences, 8, 14-17.

Dambolena, J. S., Zunino, M. P., López, A. G., Rubinstein, H. R., Zygadlo, J. A., Mwangi, J. W., . . Kariuki, S. T. (2010). Essential oils composition of Ocimum basilicum L. and Ocimum gratissimum L. from Kenya and their inhibitory effects on growth and fumonisin production by Fusarium verticillioides. Innovative Food Science and Emerging Technologies, 11, 410-414.

Demigne, C., Sabboh, H., Re'me', S., and Meneton, P. (2004). Protective effects of high dietary potassium in Nutritional and metabolic aspects. Journal of Nutrition, 134, 2903-2906.

Ehiagbonare, J. (2007). Macropropagation of Ocimum gratissimum L: A multi purpose medicinal plant in Nigeria. African Journal of Biotechnology, 6, 13-14.
Emeka, N. G., and Chimaobi, A. (2012). Chemical composition and variability among some Ocimum gratissinum accessions. International Journal of Medical and Aromic Plants, 2, 460-467.

Gholap, S., and Kar, A. (2004). Hypoglycaemic effects of some plant extracts are possibly mediated through inhibition in corticosteroid concentration. Die Pharmazie-An International Journal of Pharmaceutical Sciences, 59, 876-878.

Gupta, P., Yadav, D. K., Siripurapu, K. B., Palit, G., and Maurya, R. (2007). Constituents of Ocimum sanctum with antistress activity. Journal of natural products, 70, 1410-1416. Idris, S., Iyaka, Y., Ndamitso, M., and Paiko, Y. (2011). Nutritional Composition of the Leaves and Stems of Ocimum gratissimum. Journal of Emerging Trends in Engineering and Applied Sciences, 2, 801-805.

Joshi, S., Bothara, S., and Surana, S. (2011). Evaluation of aqueous extract of Ocimum sanctum in experimentally induced parkinsonism. Journal of Chemical and Pharmaceutical Research, 3, 478-487.

Kashif, M., and Ullah, S. (2013). Chemical composition and minerals analysis of Hippophae rhamnoides, Azadirachta indica, Punica granatu and Ocimum sanctum leaves. World Journal of Dairy and Food Science, 8, 67-73.

Khandelwal, K. (2007). Practical pharmacognosy techniques and experiments (17th ed.). Nirali Prakashan, India.

Kirk, S., and Sawyer, R. (1991). Pearson's composition and analysis of foods, England Longman scientific and technical: Longman Group Ltd.

Lewu, M., Adebola, P., and Afolayan, A. (2010). Effect of cooking on the mineral contents and anti-nutritional factors in seven accessions of Colocasia esculenta (L.) Schott growing in South Africa. Journal of Food Composition and Analysis, 23, 389393.

Mequanint, W., Makonnen, E., and Urga, K. (2011). In vivo anti-inflammatory activities of leaf extracts of Ocimum lamiifolium in 
mice model. Journal of Ethnopharmacology, 134, 32-36.

Mlitan, A., Sasi, M., and Alkherraz, A. (2014). Proximate and minor mineral content in some selected basil leaves of Ocimum gratissimum L, in Libya. International Journal of Chemical Engineering and Applications, 5, 502.

Nakamura, C. V., Ueda-Nakamura, T., Bando, E., Melo, A. F. N., Cortez, D. A. G., and Dias Filho, B. P. (1999). Antibacterial activity of Ocimum gratissimum L. essential oil. Memórias do Instituto Oswaldo Cruz, 94, 675-678.

Njoku, P., and Ohia, C. (2007). Spectrophometric estimation studies of mineral nutrient in three cocoyam cultivars. Pakistan Journal of Nutrition, 6, 616-619.

Oboh, F. O., Masodje, H. I., and Enabulele, S. A. (2009). Nutritional and antimicrobial properties of Ocimum gratissimum leaves. Journal of Biological Sciences, 9, 377-380.

Okunlola, A., Ogungbite, O., and Hassan, G. (2017). Growth and nutritional qualities of three ocimum species as affected by methods of propagation. East African Agricultural and Forestry Journal, 82, 3646.

Pachkore, G., and Dhale, D. (2012). Phytochemicals, vitamins and minerals content of three Ocimum species. Internation Journal of Science Innovations and Discoveries, 2, 201-207.

Paton, A. (1992). A synopsis of Ocimum L. (Labiatae) in Africa. Kew Bulletin, 47, 403435.

Prakash, P., and Gupta, N. (2005). Therapeutic uses of Ocimum sanctum Linn (Tulsi) with a note on eugenol and its pharmacological actions: a short review. Indian Journal of Physiology and Pharmacology, 49, 125.

Prashar, R., Kumar, A., Hewer, A., Cole, K. J., Davis, W., and Phillips, D. H. (1998). Inhibition by an extract of Ocimum sanctum of DNA-binding activity of 7, 12dimethylbenz [a] anthracene in rat hepatocytes in vitro. Cancer letters, 128, 155-160.
Saha, S., Dey, T., and Ghosh, P. (2010). Micropropagation of Ocimum kilimandscharicum Guerke (labiatae). Acta Biologica Cracoviensia Series Botanica, 52, 50-58.

Saha, S., Kader, A., Sengupta, C., and Ghosh, P. (2012). In vitro propagation of Ocimum gratissimum L. (Lamiaceae) and its evaluation of genetic fidelity using RAPD marker. American Journal of Plant Sciences, 3, 64-74.

Shuaib, O., Adeniran, O., Musah, M., Yerima, H., Sani, H., and Amusat, K. (2015). Comparative nutritional and anti-nutritional analysis of Ocimum grattissimum and Ocimum basilicum. Academia Arena, 7, 7781.

Singh, D., and Chaudhuri, P. K. (2018). A review on phytochemical and pharmacological properties of Holy basil (Ocimum sanctum L.). Industrial Crops and Products, 118, 367-382.

Singh, S., and Agrawal, S. S. (1991). Antiasthmatic and anti-inflammatory activity of Ocimum sanctum. International Journal of Pharmacognosy, 29, 306-310.

Singh, S., Majumdar, D., and Rehan, H. (1996). Evaluation of anti-inflammatory potential of fixed oil of Ocimum sanctum (Holybasil) and its possible mechanism of action. Journal of Ethnopharmacology, 54, 19-26.

Siti, M. Y., Rabeta, M., and Antora, R. (2018). Effects of different drying methods on the proximate composition and antioxidant activities of Ocimum basilicum leaves. Food Research, 2, 421-428.

Sofowora, A. (1993). Phytochemical Screening of Medicinal Plants and Traditional Medicine in Africa (2nd ed.). Spectrum Books Ltd, Ibadan, Nigeria.

Vidhani, S. I., Vyas, V. G., Parmar, H. J., Bhalani, V. M., Hassan, M. M., Gaber, A., and Golakiya, B. A. (2016). Evaluation of some chemical composition, minerals fatty acid profiles, antioxidant and antimicrobial activities of Tulsi (Ocimum sanctum) from India. American Journal of Food Science and Technology, 4, 52-57. 